\title{
The 100\% money proposal and its implications for banking: The Currie- Fisher approach versus the Chicago Plan approach
}

\author{
Samuel Demeulemeester \\ ENS de Lyon (Triangle) and Université Paris 8 (LED) \\ Email: samuel.demeulemeester@ens-lyon.fr
}

\begin{abstract}
The literature on the $100 \%$ money proposal often reveals some confusion when it comes to its implications for the banking sphere. We argue that this can be partly explained by a failure to have distinguished between two divergent approaches to the proposal: the 'Currie-Fisher' (or 'transaction') approach, on the one hand, which would preserve banking; and the 'Chicago Plan' (or 'liquidity') approach, on the other hand, which would abolish banking. This division among $100 \%$ money proponents stemmed, in particular, from different definitions of money, and different explanations of monetary instability. The present paper attempts to clarify this divergence of views.
\end{abstract}

\section{Key words}

100\% money, banking, Chicago Plan, Lauchlin Currie, Irving Fisher

\section{JEL codes}

B22, B31, E42, E50, E51, G20, G21

\section{Introduction}

The $100 \%$ money proposal has aroused renewed interest, following the 2007-8 global financial crisis and ensuing recession, as a potential solution to improve monetary control and stabilize the economy. Its advocates, viewing money creation out of bank loans as a major source of instability, would make all issuance of money (including checking deposits) a monopoly privilege of the state. This proposal was first widely discussed in the context of the 
Great Depression of the 1930s, when it was supported by different authors, in various versions ${ }^{1}$. One was embodied in the so-called 'Chicago Plan' for banking reform, exposed in a series of memoranda co-authored by a group of Chicago economists in $1933^{2}$ and, subsequently, in the writings of Henry Simons (from 1934). Other versions were designed, at that time, by Lauchlin Currie (from 1934), Irving Fisher (from 1935), or James Angell (1935), while several bills calling for a $100 \%$ money reform were introduced in the U.S. Congress in the 1930s and 1940s. The proposal was later advocated by Maurice Allais (from 1947), Milton Friedman (from 1948), James Tobin (from 1985) and Hyman Minsky (from 1994), and has kept appearing in new versions up till today ${ }^{3}$. The history of all these reform plans has been well documented, particularly in a book by Ronnie J. Phillips (1995) ${ }^{4}$. The concept of $100 \%$ money, however, still requires clarification, especially when it comes to its implications for the banking sphere-as was revealed, for example, by a review of Phillips's book by Schiming (1996, p. 265). The recent literature on the subject, in particular, shows a great deal of confusion in that respect. We argue that this is partly due to a failure to have distinguished between two divergent approaches to the proposal, insofar as banking activity-defined here as the activity of financing loans and investments out of collected deposits 5 -was concerned.

${ }^{1}$ The idea that private banks should be prevented from creating money can be found in the writings of
David Ricardo already, as well as in the Currency School arguments which led to the adoption of the
English Bank Charter Act of 1844 . All those writers, however, focused on the issuance of bank notes,
without considering transferable bank deposits as money. The proposal for a $100 \%$ reserve
requirement behind checking deposits seems to have appeared in the United States, in the mid-19
century, with authors such as Charles H. Carroll (see Mints, 1945, pp. 154-6). Léon Walras, in 1898,
also suggested that all checking accounts be kept in a central "Transfer Bank" ["Banque de
virements"], with 100\% reserves behind them, so that "monetary circulation would not be disturbed by
the arrangements of credit" ["que la circulation monétaire ne soit pas troublée par les combinaisons
du crédit'] (Walras, 1898, pp. 376, 395, my translation). Early $20^{\text {th }}$ century advocates of 100\%
reserves included Frederick Soddy (1933 [1926], pp. 229-31), whose proposal, based on 'fiat money'
reserves, might have influenced the Chicago Plan directly (Phillips, 1995, p. 46).
2 This group included Garfield Cox, Aaron Director, Paul Douglas, Frank Knight, Albert G. Hart,
Lloyd Mints, Henry Schultz, and Henry Simons. They circulated three memoranda in 1933 (see
Phillips, 1995, pp. 47-68): the first in March (Knight et al., 1995 [1933]), the second-a revised
version of the first by Simons-in April (unpublished), and the third- mainly the work of Simons-in
November (Simons et al., 1994 [1933]). As noted by David Laidler (1999, p. 231), the term 'Chicago
Plan' was coined by Hart (1935), whereas '100\% money' was Fisher's phrasing.

${ }^{3}$ See, for example, Huber and Robertson (2000), Kotlikoff (2010), Benes and Kumhof (2012), Jackson and Dyson (2013), Sigurjónsson (2015), Levitin (2016), or Huber (2017). Patrizio Lainà (2015) has recently provided a historical overview of what he terms "full-reserve banking proposals".

${ }^{4}$ One can also refer to Phillips (1988) and Whalen (1994) for discussions about the Chicago Plan; to Sandilands (2004) about Currie's plan; and to Allen (1993), Dimand (1993) and Fisher (1997b [1935], editorial content) about Fisher's plan.

5 'Banking' could be more properly defined as consisting of two sets of activities, one related to the administration of the payment system (deposit-keeping and transferring), the other to the 
Two groups of authors can indeed be distinguished, who, beyond their points of agreement, adopted opposite conclusions on this specific issue. The first group, following the views of Lauchlin Currie and Irving Fisher, supported a 100\% money proposal which would leave the proper banking sphere largely untouched-banks would remain free to perform financial intermediation by collecting and lending out savings deposits. The second group, following the views of the Chicago Plan, called for a drastic transformation, if not the complete abolition, of banking - banks would be replaced, in their intermediation function, by equityfinanced institutions such as investment trusts. These diverging attitudes, as we will see, mainly stemmed from different definitions of money and different explanations of monetary instability. The conflict between the two approaches, however, has not been clearly identified and discussed in the literature. Although Phillips was aware of these differences, he chose not to look into them in his book:

Though both Fisher and the Chicago economists would be classified as adherents to the Quantity Theory of Money (QTM), they had differences of interpretation. A careful analysis of the respective interpretations would undoubtedly provide insight into their differences over stabilization schemes. Because it goes beyond the intent of the present study, comparisons of their views will be restricted to correspondence between Fisher and Simons . . ., and no attempt to compare and contrast their somewhat different versions of the QTM will be attempted. (Phillips, 1995, p. 206)

The purpose of the present paper is precisely to take over Phillips's work on this question, and elucidate the confrontation between those two approaches to the $100 \%$ money proposalwhich we call the 'Currie-Fisher approach' (or 'transaction approach') on the one hand, and the 'Chicago Plan approach' (or 'liquidity approach') on the other hand. To this end, after having presented the common features of the two approaches, we will study their divergences on three different levels: the definition of money, the explanation of monetary instability, and the treatment of banking ${ }^{6}$. Finally, we will see how the lack of distinction between the two approaches in the literature has led to recurrent misconceptions about the $100 \%$ money proposal, including in the most recent and still ongoing discussions of the idea ${ }^{7}$.

intermediation between savers-depositors and investors-borrowers (deposit-lending). In this paper, however, we tend to use the term to refer to this latter activity specifically.

${ }^{6}$ One can refer to Table 5, in the concluding section, for a summary of these divergences.

${ }^{7}$ These divergences between the 'transaction' and 'liquidity' approaches can also be found in the proposals for 'narrow banking' which appeared in the 1980s (see, for example, Litan, 1987). 


\section{Common features of the two approaches}

2.1. The creation of means of payment out of banking activity viewed as a major factor of economic instability

All 100\% money proponents shared a major criticism of the existing monetary system, in which bank promises to pay (deposits), covered only fractionally by reserves in lawful money, were used as means of payment. Such a system, they said, was inherently unstable: the expansion of bank loans would lead to excessive money creation in the upswing phase of business, producing a boom, while their contraction would lead to excessive money destruction in the downswing phase, producing a depression. The situation could then be further aggravated by bank failures, as the great monetary contraction of 1929-33 illustrated. Of course, as those authors generally conceded, booms and depressions could theoretically be prevented if adequate countercyclical action was taken by the monetary authority. But such action, in the existing system, was particularly uneasy as it always had to be exercised 'against the wind'. Moreover, even if successful, it would come at the price of a manipulation of the rate of interest by the central bank, which, it was argued, could cause severe market disturbances. For these reasons, the $100 \%$ money proponents recommended a drastic change of the monetary system.

\subsection{A $100 \%$ reserve requirement on bank deposits subject to check}

As summarized by Fisher (1997b [1935], p. xvii), “[t]he essence of the 100\% plan is to make money independent of loans; that is, to divorce the process of creating and destroying money from the business of banking". The core of the reform, common to both approaches, was to require the banks to keep $100 \%$ reserves in lawful money behind their deposits subject to check, fulfilling a payment function. These transferable deposits would be kept in a check department, or check bank, which would act as a mere 'warehouse' for funds, providing their depositors with payment facilities. In no case could these funds be used by the bank to finance loans or investments. This provision, beyond allowing direct control over the volume of checking deposits by the monetary authority, would offer the additional advantage of securing the payment system from bank runs. As to the question of how the administration of checking accounts should be remunerated, various options were suggested, such as applying service charges to account holders, subsidizing the banks, or transferring this activity to public 
agencies, like the postal savings system or even the central bank itself ${ }^{8}$. But apart from these technical (though important) considerations, all versions of the proposal agreed on the treatment to be given to checking deposits. They disagreed sharply, however, on the treatment to be given to savings deposits, fulfilling an investment function-as we will see in section 5 . At any rate, financial intermediation would remain a prerogative of the private sphere, as avoiding the nationalization of banks was a motivation common to all versions of the plan ${ }^{9}$.

\subsection{A monetary authority responsible for all money issuance}

Under all $100 \%$ (fiat) money proposals ${ }^{10}$, the function of creating or destroying money would become an exclusive privilege of the state ${ }^{11}$. This would apply to all means of payment, including checking deposits, as the latter would be fully covered by reserves in lawful money. The money supply, under most proposals, would be regulated by an independent monetary authority, subject to a rule of objective to be adopted by Congress (such as a price-level stabilization rule). Some proposals would submit the monetary authority not only to a rule of objective, but also to an automatic rule of action, while others insisted that it should be awarded discretionary powers of implementation. Discussing these questions of monetary policy, however, is beyond the scope of this paper. As for the practical modalities of money injection, most proposals recommended that the monetary authority regulate the volume of money exclusively by buying or selling government securities in the open market. These securities could be either existing bonds, or new bonds issued by the Treasury ${ }^{12}$. In the latter case, the new money might be spent directly by the government, credited to taxpayer accounts, or even distributed to citizens in the form of a social dividend. Under most plans,

\footnotetext{
${ }^{8}$ For discussions regarding the implementation of the $100 \%$ money proposal under its various versions, one can refer, for example, to Hart (1935), Watkins (1938) or G.R. Barber (1973).

${ }^{9}$ For Fisher (as for Simons), the stakes were even higher: "[t]he best available safeguard against the overthrow of capitalism is the $100 \%$ system, combined with money management, to give us a stable dollar. Of all people, bankers should, therefore, favor this proposal if only in self-defense. Otherwise, by the irony of fate, they may someday be the ones to upset capitalism" (Fisher, 1997b [1935], p. 219).

${ }^{10}$ Those should be distinguished, however, from the $100 \%$ gold reserve proposals, which have been developed by economists of the Austrian school in particular-see, for example, Ludwig von Mises (1924 [1912], p. 408) or Murray Rothbard (1962). One can refer to Jesús Huerta de Soto (2012 [1998], pp. 715-35) for a historical overview of the $100 \%$ gold reserve theory-which, although its analysis of economic instability is most interesting, falls outside the scope of this paper.

${ }^{11}$ The $100 \%$ money idea should not, either, be confused with the 'modern monetary theory' (MMT) expounded by authors such as L. Randall Wray (2015) [2012]. Indeed, while stressing the monetary role played by the state, MMT insists that the banks should remain involved in money creation too.

${ }^{12}$ Because the state, via its monetary authority, would be buying its own bonds, it was usually argued that the public debt would not be aggravated—and could even be reduced—by money injections.
} 
the discount window would be abolished. Again, discussing these modalities is beyond the scope of our present study.

\section{Divergences about the definition of money}

\subsection{The Currie-Fisher approach: Money as means of payment, and only means of payment}

The first point of divergence among the authors discussed in this paper concerns the very concept of money itself. Currie and Fisher, in their advocacy of the $100 \%$ money proposal, used a strict definition of money, the perimeter of which was clearly delimited. They basically included in the money supply all means of payment, and only means of payment.

These two authors first questioned the narrow perimeter of the traditional definition, limited to "what is generally acceptable for goods", as Fisher himself used to describe money in earlier writings (1997a [1911], p. 8). Under the new definition he provided, the adjective 'generally' was replaced by 'commonly':

Money is any form of property which is commonly used as a means of exchange for other forms of property-in short, as a means of payment. It includes the ordinary "pocket-book money" and also what may be called "check-book money". (Fisher, 1947, p. 1) ${ }^{13}$

Currie, dedicating a whole book chapter to defining the concept of money, argued in the same direction: "[t]he words 'generally acceptable' exclude any instruments acceptable only in particular circumstances, such as debt due an individual by a banker which may be transferred by order of the individual" (Currie, 1968a [1934], p. 10). He thus proposed to widen the meaning of the term, "so as to make it synonymous with means of payment" (ibid.). He went on to stress the character of money as a debt-paying instrument:

[T] he distinguishing characteristic of money [is] the power of settling transactions. . . Our definition of money, then, is those instruments possessed by the public by delivery of which debt contracts and price contracts are discharged. (Currie, 1968a [1934], p. 11)

As for the cash and the central bank deposits that were held by the banks, Currie noted that, "strictly speaking", they "constitute[d] means of payment" (ibid., p. 13). However, insofar as they were used as reserves behind checking deposits, they should be excluded from the money supply compilation, because including both those deposits and the reserves backing them "would obviously involve double counting" (ibid., p. 12). Hence, if we extrapolate from

\footnotetext{
${ }^{13}$ This definition was implicitly contained, but not explicitly formulated, in his book $100 \%$ Money.
} 
Currie's logic, the total money supply $(M)$ could be regarded as the union of two sets of means of payment, lawful (or 'base') money $(M o)$ and bank money $\left(M^{\prime}\right)^{14}$, such as:

$$
M=M o \cup M
$$

This is illustrated in Figure 1. The intersection of the two sets $\left(M o \cap M^{\prime}\right)$ would represent the part of bank money covered by reserves in lawful money ${ }^{15}$. Those units should only be counted once in the money supply, to avoid double counting. The total number of monetary units would thus be equal to:

$$
|M|=\left|\operatorname{MoU} M^{\prime}\right|=|M o|+\left|M^{\prime}\right|-\left|M o \cap M^{\prime}\right|
$$

Figure 1 The total volume of means of payment under the fractional-reserve money system

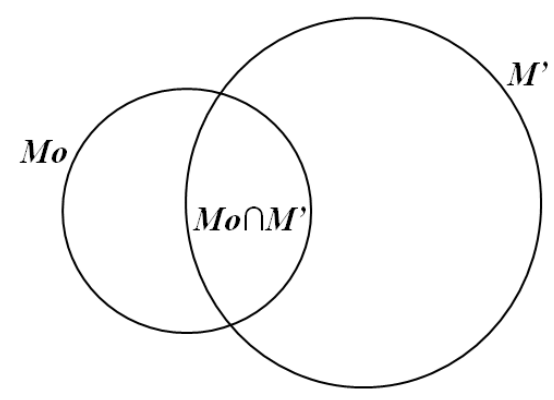

However, although they virtually included all means of payment in their definition of money, Currie and Fisher categorically refused to include assets that could not directly fulfil this payment function, even those presenting the highest level of liquidity. Savings deposits, in particular, even if available 'on demand', were not regarded as money. According to Currie:

It is claimed, and quite rightly, that banks practically never invoke the privilege of postponing payment of time deposits and that therefore they are, in effect, actually payable on demand. From this fact certain writers have been led to the conclusion that time deposits, from the point of view of their owners, may be regarded as the equivalent of cash. There is, however, an important distinction between means of payment and what may be regarded by individuals as equivalent to means of payment. Time deposits, in this respect, do not differ essentially from holdings of

\footnotetext{
${ }^{14}$ For the sake of simplification, we limit our analysis here to those two kinds of money. Historically, however, other instruments have been used as means of payment, such as various kinds of commodities, commercial paper, shares of money market mutual funds, or, more recently, cryptocurrencies.

15 This quantity of reserves used by the banks to cover their checking deposits (equal to MonM'), however, does not represent the totality of bank reserves, insofar as part of those are kept for other purposes - for example, as reserves behind savings deposits, or for the banks' own transaction needs.
} 
government securities, call loans, or, indeed, any property possessing good marketability which by sale can be converted into means of payment. (Currie, 1968a [1934], p. 14, original italics)

He went on:

If we are to include with means of payment all factors which contribute to economy of means of payment, it is difficult to see where we should stop, and the concept of money would become so broad as to be useless. (ibid., p. 18)

Fisher developed a similar analysis:

It can scarcely be too much emphasized that a savings deposit, without the checking privilege, is vitally different from a checking deposit. . . . A savings deposit ought not to be called a deposit at all. It is not money, and is not ordinarily used as money. It is merely a 'quick asset' like a Liberty Bond which can be more readily sold than ordinary assets. (Fisher, 1997b [1935], pp. 168-9)

Both authors, therefore, held a strictly delimited concept of money.

\subsection{The Chicago Plan approach: The concept of money extended to liquid assets}

In contrast to Currie and Fisher, the authors of the Chicago Plan rejected any definition of money as limited to means of payment. Simons severely criticized Currie on this point, in a review of the latter's book:

On several crucial points. . . . Dr. Currie's position is, to the reviewer, highly unsatisfactory. He contends that only actually circulating media should be regarded as money. (Simons, 1935, p. 556)

Simons, however, did not provide any alternative definition of his own. He seemed to extend the concept of money to whatever assets that were easily convertible into means of payment, like savings deposits, but with no clear boundary to be drawn:

At all events, it seems likely that we shall make substantial progress . . . only by facing squarely the task of working with that concept of money which Currie describes as "so broad as to be useless". . . . We must see that there is little significant difference between demand deposits and savings accounts, and that all institutional borrowing and lending at short term presents the same problems and anomalies as does deposit banking. The criterion of "effective circulation", like legal tender and "general acceptability", must not be taken too seriously. (Simons, 1935, p. 557)

Other 100\% money proponents, such as Angell (1935, p. 2) and Friedman (1992 [1960], pp. 90-1), also included savings deposits in their broad concept of the money supply. So did Maurice Allais, who held a position close to that of Simons: 
In my view . . the quantity of money held by an operator is the portion of his assets he rightly or wrongly believes he can use to make his payments immediately and without restriction. (Allais, 1987, p. 502; see also 1975 , pp. 120-1)

He went on to extend his concept of money to a very wide range of assets:

Creation of money is not limited to the uncovered portion of demand-deposits; a share of time deposits also enters the process.... Similar remarks can, of course, be made about the other assets held by operators, ranging from treasury bills (almost fully liquid) to real estate (perhaps the most illiquid form of all). To each may be ascribed a substitutability ratio defining its ability to be considered as potential cash balances. (Allais, 1987, pp. 507-8) ${ }^{16}$

Allais recognized, however, that so broad a definition complicated the calculation of the money supply: "From this standpoint the money supply M is largely a psychological concept, and, therefore, seems to escape objective evaluation" (ibid., p. 509, original italics). The issue raised by Currie, of deciding where to stop once one started to include liquid assets into the money supply, was thus left unsolved under this approach.

\section{Divergences about the leading causes of monetary instability}

\subsection{The Currie-Fisher approach: The creation of means of payments through banking as the} one leading factor of monetary instability

All proponents of the $100 \%$ money reform, as we mentioned earlier, viewed the dependence of the medium of exchange upon banking activity as a source of inherent economic instability ${ }^{17}$. Such dependence, they argued, tended to produce either a cumulative expansion

\footnotetext{
${ }^{16}$ Allais thus defined the money supply as: $M(t)=M_{l}(t)+\int_{t}^{\theta} \sigma^{*}(t, \theta) p^{*}(t, \theta) d \theta+\sum_{i} \sigma_{i}(t) q_{i}(t)$, "where $M_{l}(t)$ is the volume at time $t$ of the basic money in circulation outside the banking system plus demand deposits held by private individuals; $p^{*}(t, \theta) d \theta$ is the volume of time deposits at time $t$ whose term lies between $\theta$ and $\theta+\mathrm{d} \theta ; \sigma^{*}(\mathrm{t}, \theta)$ is the average of the corresponding substitutability ratio, and the $q_{i}(t)$ are assets other than deposits at time $t$ with rates of substitutability against cash of $\sigma_{i}(t)$ " (Allais, 1987, pp. 508-9, original italics; see also 1975, p. 126).

${ }^{17}$ With the exception, however, of Milton Friedman, whose arguments for $100 \%$ reserves fell under neither of the two approaches discussed in this paper. Friedman assigned the "inherent instability" of the fractional-reserve monetary system only to the "decisions by holders of money about the form in which they want[ed] to hold money and by banks about the structure of their assets" (1992 [1960], p. 66). He further criticised that system for "involv[ing] extensive governmental intervention into lending and investing activities" (ibid.). But he was not specifically opposed to the creation of money out of bank loans. Indeed, alternatively to $100 \%$ reserves, he was ready to consider completely opposite solutions: either to allow the banks "to issue currency as well as deposits" (ibid., pp. 68-9), or "to permit 'free' deposit banking, without any requirements about reserves" (ibid., p. 108).
} 
or a cumulative contraction of the money supply, which, unless counteracted, would lead to alternations of booms and depressions. Thus, according to the Chicago economists:

[Such a system] gives us an unreliable and unhomogeneous medium; and it gives us a regulation or manipulation of currency which is totally perverse. Money is created when it should be destroyed, and destroyed when it should be created. (Simons et al., 1994 [1933], p. 31)

Fisher described the cumulative processes affecting the money supply in the following terms:

[The tie between money and debt] causes the banks, by means of business debts, to keep everlastingly tinkering with our currency and so causes unnatural inflations and unnatural deflations. For, under the $10 \%$ system $^{18}$ it is true, as we have seen, that an increase in business, by increasing commercial bank loans, and so increasing the circulating medium, tends to raise the price level. And, as soon as the price level rises, profits are increased and so business is expanded further. Thus comes a vicious circle in which business expansion and price expansion act each to boost the other-making a "'boom". Reversely if business recedes, loans and prices also recede, which reduces profits and so reduces business volume - again causing a vicious circle, making a “depression”. (Fisher, 1997b [1935], pp. 180-1)

By calling $P$ the general level of prices ${ }^{19}, D$ the volume of bank loans (debt), and $M^{\prime}$ the total of bank money, we could summarize these cumulative processes in the following way:

In the boom phase: $\quad \uparrow P \rightarrow \uparrow D \rightarrow \uparrow M^{\prime} \rightarrow \uparrow P$, and so on.

In the depression phase: $\downarrow P \rightarrow \downarrow D \rightarrow \downarrow M^{\prime} \rightarrow \downarrow P$, and so on.

Hence, with such chain reactions, the causality between variations in $M$ and variations in $P$ appeared to be reciprocal, "with new money raising prices and rising prices conjuring up new money" (Fisher et al., 1939, p. 4). It also followed, from this analysis, that the reserve-deposit ratio (and, more generally, the $M o / M^{\prime}$ ratio $^{20}$ ) would never be constant; it would tend to decrease in boom phases, and to increase in depression phases. This would make the control of the total money supply by the monetary authority very challenging, as Currie noted:

\footnotetext{
${ }^{18}$ Fisher referred to the fractional-reserve money system as the ' $10 \%$ system', in contrast with the ' $100 \%$ system' he was calling for.

${ }^{19}$ With $P$ here representing all prices (including, for example, asset or house prices), although, in practice, Fisher usually recommended the use of "a fixed index of the cost of living" as a criterion of stability (Fisher, [1997b] 1935, p. 97).

${ }^{20}$ The constant instability of this ratio had been noted by Fisher in 1911 already (1997a [1911], pp. 5573).
} 
[I]t is possible to generalize that on the upswing of the business cycle the supply of money automatically tends to expand, and on the downswing to contract. The automatic forces, in other words, tend on balance to operate against the customary central bank policy, thus rendering the task of control more difficult. In so far as this is true we may say that the supply of money under the Federal Reserve System displays a perverse elasticity. (Currie, 1968a [1934], p. 131)

For all these authors, the problem needed to be tackled at source. The tie between $D$ and $M^{\prime}$ had to be severed, so that the chain of reactions described above could no longer develop into cumulative processes. This required divorcing the creation and destruction of checking deposits $\left(M^{\prime}\right)$ from the extension and contraction of bank loans $(D)$, by subjecting these deposits to a $100 \%$ reserve requirement (see section 5). Beyond this point of consensus, however, a divergence would appear among the $100 \%$ money proponents. For the Chicago Plan economists, the tie between $D$ and $M$ ' only represented one major factor of instability, but another factor of equal importance-the tie between $D$ and $V$ (the velocity of 'effective money') — still had to be dealt with (see section 4.2). For Currie and Fisher, on the contrary, the creation of means of payment through banking represented the one leading cause of monetary instability, which alone they endeavoured to tackle.

Of course, both Currie and Fisher were aware that other factors came into play in causing business cycles. Fisher thus listed nine variables explaining booms and depressions, which tended to interact with one another: "debts, the volume of circulating medium, its velocity of circulation, price levels, net worths, profits, trade, business confidence, interest rates" (Fisher, 1997b [1935], pp. 121-3). But he assigned a leading role, above all, to the variations of $M^{\prime}$, insisting that, in the case of a depression, "practically all the events listed occur[ed] through a contraction of check-book money" (ibid., p. 123, original italics). In sharp contrast with Simons (see section 4.2), Fisher was not obsessed with the risk of variations in the velocity of money $(V)$. He certainly recognized that such variations could be an important factor of disturbances, when large hoarding or dishoarding movements took place. The banking crises of the early 1930s, after all, had largely been the results of runs on savings or time deposits, which were not subject to check (Fisher, 1997b [1935], p. 167). But, according to him, "the runs on savings banks usually follow[ed] contraction of the medium of exchange and the appreciation of the dollar", and, "given stability of the dollar, runs on savings banks would be extremely rare" (ibid., pp. 166, 170). In other words, the changes in $V$ tended to follow and aggravate the disturbances occasioned by the changes in $M$, rather than to cause those 
disturbances in the first place ${ }^{21}$. Fisher thus seemed to consider that major banking crises could not happen independently from monetary crises. Of course, sudden shifts in desired money holdings, even if less severe, could still occur under a $100 \%$ system. But even in this case, he argued, variations of $V$ could always be compensated by adequate variations of $M$ :

[Under the $100 \%$ system], the velocity of circulation might still be subject to various untoward disturbances. For instance, after a period of over-indebtedness and speculation, there might still be a stampede of distress selling and therefore increased hoarding; that is, there might be a slowing of velocity. The effect of this on the price level, however, would be much smaller than if the volume of circulation were also affected; and even the velocity effect on the price level could probably be offset by a suitable increase in volume. (Fisher, 1997b [1935], p. 102)

Such "suitable increase in volume", moreover, could be achieved much more easily under the $100 \%$ system than under the present bank-money system (ibid., p. 108) ${ }^{22}$. On all these matters, Currie's analysis appeared to be close to Fisher's (see Currie, 1968a [1934], p. 143).

It follows from these authors' viewpoint that, if one could prevent the sharp variations in the volume of checking deposits from happening, then sharp variations in the volume of savings deposits would also, most likely, be prevented. This explains why, as we will see in section 5, savings deposits would not be affected under Currie's and Fisher's reform plans. The full coverage of checking deposits would suffice, by itself, to mitigate-if not to abolish - the "great booms and depressions", Fisher argued (1997b [1935], p. 151, original italics). This conclusion was not shared, however, by the authors of the Chicago Plan.

4.2 The Chicago Plan approach: The creation of liquidity through banking as another leading factor of monetary instability

\footnotetext{
${ }^{21}$ On this point, Fisher's position would find support in empirical works. Clark Warburton, studying velocity changes over the period 1919-47, concluded: "Factual information for the period since 1919 does not support the assumption that variations in monetary velocity are an initial factor in business depression. The data do, however, indicate that in some cases a declining velocity of money has accompanied and in other cases has followed downward deviations from trend in the quantity of money. In fact, after a business recession has run for a time and the quantity of money has been reduced, there is almost uniformly a slowing down in velocity, relative to trend, which is reversed only when the shrinkage in the money supply is known, or believed, to have been stopped. There is no evidence that disturbances to economic equilibrium originate in an erratic rate of use of money, but there is much evidence that such disturbances result in, and are in turn intensified by, variations from trend in the rate of use of money" (Warburton, 1949, p. 91). Milton Friedman and Anna Schwartz (1963, p. 682), studying the period 1867-1960, reached convergent conclusions.

${ }^{22}$ Fisher insisted that some discretionary powers of action should be left to the monetary authority, allowing it to successfully stabilise the general price level (Fisher, 1997b [1935], p. 24). He thus advocated what we would call today a 'constrained discretion' for the Currency Commission.
} 
The Chicago Plan authors, as we have seen, similarly held the view that the creation of means of payment out of bank loans led to cumulative maladjustments in the money supply. Contrary to Currie and Fisher, however, they also attributed a leading role, and not simply an aggravating one, to the variations of the velocity of 'effective money' in causing business cycles. In their November 1933 memorandum, they thus insisted that "monetary changes merely on the velocity side might produce substantial cyclical fluctuations" (Simons et al., 1994 [1933], p. 42) ${ }^{23}$. To illustrate this fact, the Chicago economists started their explanation of cumulative processes by focusing solely on the link between debt and velocity:

[A]ny general change in business earnings will affect promptly the speculative temper of the community. Larger profits breed optimism; they stimulate investment and induce dishoarding . . Producers will become more anxious to borrow . . . Lenders will have fewer misgivings about the ability of borrowers to repay. People generally will increase their lending and investment at the expense of their idle reserves of cash. In a word, the velocity of circulation will increase. But this change, in turn, means a larger volume of business and higher product-prices, and thus still larger earnings. The further increase of earnings, moreover, will induce further increase in the velocity of money. And so on and on. . (Simons et al., 1994 [1933], p. 46)

This chain of reactions, involving business earnings $(\pi)$, debt $(D)$ and the velocity of the circulating media $(V)$, may be summarized in the following way:

In the boom phase: $\quad \uparrow \pi \rightarrow \uparrow D \rightarrow \uparrow V \rightarrow \uparrow \pi$, and so on.

In the depression phase: $\downarrow \pi \rightarrow \downarrow D \rightarrow \downarrow V \rightarrow \downarrow \pi$, and so on.

Hence, according to the Chicago Plan authors, business cycles could develop even without any change in the volume of means of payment: "So far. . . [w] have impliedly assumed an economy with a fixed (or independently variable) quantity of effective money" (ibid., p. 46). Only then did they introduce the creation and destruction of means of payments through banking in their analysis, describing the following cumulative processes (ibid., p. 47):

In the boom phase: $\quad \uparrow \pi \rightarrow \uparrow D \rightarrow \uparrow M^{\prime} \rightarrow \uparrow \pi$, and so on.

\footnotetext{
${ }^{23}$ However, there did not seem to be a complete consensus among the authors on this point, as the following passage indicates: "some of us are inclined to feel that the disturbances occasioned merely by changes of velocity are unlikely to be of serious magnitude" (Simons et al., 1994 [1933], p. 42). Friedman (1967, p. 12) would also disagree with his former teacher on this issue: "The movements in velocity - which Simons took as an independent source of instability - come later than the movements in the quantity of money and are mild when the movements in the quantity of money are mild. They have been sharp only when there have been sharp movements in the quantity of money".
} 
In the depression phase: $\downarrow \pi \rightarrow \downarrow D \rightarrow \downarrow M^{\prime} \rightarrow \downarrow \pi$, and so on.

Thus, while in the Currie-Fisher analysis, the link between $D$ and $M$ was given precedence over the link between $D$ and $V$, the Chicago Plan authors seemed to put both links on the same footing. They turned their attention, therefore, to what they considered a chief cause of exacerbation of the changes in $V$ : the creation of liquid assets (or 'near monies') by the banks, in the form of savings deposits not subject to check. Through the means of saving deposits, indeed, the banks could, at the same time, provide their savers-depositors with assets claimable at short term and at a fixed nominal value, and finance loans and investments of a longer term and a riskier nature. This double transformation of risks and maturities enabled the banks to attract idle savings, thereby increasing $V$. But this also meant, in return, that $V$ would sharply fall, should these claims be massively exercised at once. This led the Chicago economists, and Simons in particular, to put into question the very essence of banking:

There is likely to be extreme economic instability under any financial system where the same funds are made to serve at once as investment funds for industry and trade and as the liquid cash reserves of individuals. (Simons, 1948 [1934], p. 320, original italics)

What matters is the character of the financial structure which banking creates - and the fact that, in the very nature of the system, banks will flood the economy with money-substitutes during booms and precipitate futile efforts at general liquidation afterward. (Simons, 1936, pp. 9-10)

The condemnation of the creation of liquidity by banks, through their performing of risk and maturity transformation, was implicitly contained in all the schemes which called for the "abolition of deposit banking" (Simons et al., 1994 [1933], p. 32), and the replacement of banks, as lending institutions, by equity-financed investment trusts (see section 5.2). Such analysis obviously underlay the Chicago Plan memoranda of 1933. Other writers, globally sharing this approach, would condemn more explicitly either the practice of maturity transformation (Allais, 1987, p. 508), or of risk transformation (Minsky, 1994, p. 20) ${ }^{24}$. In contrast to Currie and Fisher, all those authors held, in common, the view that banking would still represent a source of systemic risk, even though banks' fractionally-covered deposits would be denied the possibility of circulating as means of payment.

\footnotetext{
${ }^{24}$ According to Charles J. Whalen (1988, p. 541), "the cycle theories of Minsky and Simons share a number of essential features", even though they are "not identical". One difference is that "[u]nlike Simons, Minsky expresses his analysis without reference to the equation of exchange" (ibid., p. 536).
} 
From 1934, however, Simons developed a somewhat different explanation of economic instability, which led him to advocate still more radical proposals. While he kept condemning the creation of liquidity by banks working with savings deposits, he now argued that "[a] major source of instability [was] also to be found in the widespread practice of borrowing at short term" (Simons, 1948 [1934], p. 320). He further made it clear that, in his view, financial instability did not ensue so much from the practice of maturity transformation (borrowing short and lending long) as it did from the mere short-term duration of debt contracts (borrowing short and/or lending short) ${ }^{25}$ :

Anyone who is not something of an economist can see that banks, acquiring funds subject to call, should lend only upon promise of early repayment; but the notion, while plausible, is entirely spurious. Indeed, the adherence to this cardinal rule of conservative lending serves (would serve), not to mitigate the affliction of banking, but to compound it; for banks thus increase the volume of short-term debts, not merely in acquiring funds, but in lending them as well. (Simons, 1936, p. 10)

This analysis, which appeared to be very specific to Simons, eventually led him to suggest the abolition of all kinds of debt contracts, as we will see in section 5.2.

\section{Divergences about banking reform}

\subsection{The Currie-Fisher approach: Keeping (fractional-reserve) banking}

The common denominator of all $100 \%$ money proposals, as we saw in section 2.2 , was to divorce the creation and destruction of means of payment from the business of banking, by imposing a $100 \%$ reserve requirement on bank deposits subject to check. This one measure, it can be argued, would not amount to altering banking practices, but, rather, to changing the social convention deciding what was acceptable or not as a medium of exchange. It was proposed that only lawful money, issued and controlled by the state, could be used as means of payment — or banks' promises to pay (deposits), provided that they were fully covered by reserves in lawful money ${ }^{26}$. This is summarized in Table 1.

\footnotetext{
${ }^{25}$ This evolution of Simons's analysis seems to have escaped Friedman, who regarded "[w]idespread borrowing on short-term in order to finance long-term obligations" as the "key to instability" in Simons's view (Friedman, 1967, p. 5).

${ }^{26}$ Of course, there were certainly very good reasons why, historically, promises to pay (issued either by banks or businesses) came to be used as means of payment - if only, to bring elasticity to the volume of money, which a metallic currency was ill-suited to provide. It follows that a major challenge for the monetary authority, under a 100\% money system, would be to adjust the money supply flexibly enough to the volume of transactions. Otherwise, economic agents might be pressured
} 
Table 1 The $100 \%$ money reform as a change of the monetary social convention

\begin{tabular}{|l|l|}
\hline Existing social convention & Proposed new social convention \\
\hline $\begin{array}{l}\text { Both lawful money and banks' promises to } \\
\text { pay (in the form of demand deposits) can be } \\
\text { accepted as means of payment }\end{array}$ & $\begin{array}{l}\text { Only lawful money (or banks' promises to } \\
\text { pay covered at 100\% by lawful money) can } \\
\text { be accepted as means of payment }\end{array}$ \\
\hline
\end{tabular}

For the Chicago Plan economists, as we will see in section 5.2, such reform would only be a first step to regain control over the whole creation of 'money' as broadly defined. But, for Currie and Fisher, who defined money as synonymous with the means of payment, this change of social convention would be sufficient, by itself, to render the money supply entirely exogenous: the total volume of money $(M)$ would become equal to the volume of lawful money $(M o)$, as the part of bank money $\left(M^{\prime}\right)$ covered by reserves would be raised to $100 \%{ }^{27}$. The following equalities would, under the Currie-Fisher approach, express the $100 \%$ money condition (as illustrated in Figure 2):

$$
\begin{gathered}
\operatorname{Mo\cap } M^{\prime}=M^{\prime} \\
M=\operatorname{Mo\cup } M^{\prime}=\text { Mo } \\
|M|=\left|\operatorname{Mo\cup } M^{\prime}\right|=|M o|+\left|M^{\prime}\right|-\left|M o \cap M^{\prime}\right|=\mid \text { Mo } \mid
\end{gathered}
$$

Figure 2 The total volume of means of payment under the $100 \%$ money system

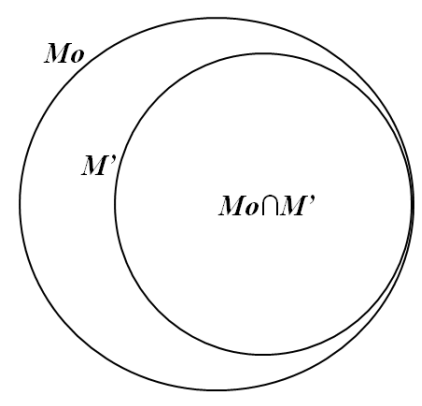

to break the law and devise alternative means of payment. Discussing this essential issue, however, is beyond the scope of our present study.

${ }^{27}$ The distinction between $M o$ and $M$ ' could even completely vanish, if all checking accounts were held on the books of the central bank directly-leaving place to a simple identity: $M \equiv M o$. This was suggested by George Tolley (1962, pp. 299-300): "Let the deposit liabilities of the commercial banks be transferred to the Federal Reserve banks. If 'reserves' are defined in the usual way, Federal Reserve liabilities connected with deposit money, there would be 100 per cent reserves in the sense that deposit money and reserves would be identical. The physical arrangements in the use of money could be continued as at present, located in the commercial banks with servicing expenses paid for on a contract basis by the Federal Reserve banks." Many of the most recent $100 \%$ money proposals have adopted this suggestion, although with differing practical arrangements. 
The banks, under this approach, would remain perfectly free to issue and multiply promises to pay beyond their cash reserves, as long as those promises were not allowed to circulate as means of payment:

Of course the volume of loans can exceed the volume of money just as sales do. The same money can negotiate one loan after another just as it can negotiate one sale after another. It can even come back to the same savings bank and be relent. So long as the loans are made out of real money and not out of money manufactured by the lender, for the purpose, they will not violate the principles of the $100 \%$ system. (Fisher, 1997b [1935], p. 90)

Thus, Currie insisted, "[b]ankers will continue to be concerned with what they have always considered their chief function, the making of loans" (1968b [1934], p. 222). Fisher affirmed, in the same vein: "[a]1l I would do is to take over the monetary work of banks, leaving real banking to bankers" (Fisher, 1934, p. 157, original italics; see also 1997b [1935], p. 202). By this 'monetary work', Currie and Fisher implied the creation of means of payment, which, in their view, should be a prerogative of the state (Currie, 1968a [1934], p. 152; Fisher, 1997b [1935], p. 19). They did not, however, aim to restrain the circulation of these means of payment by the banks, or the creation of liquid assets in the form of savings deposits, as long as those were not subject to check $^{28}$. Because they did not consider the variations of $V$ to play a leading role in monetary instability, they did not seek to alter traditional banking practices ${ }^{29}$. Under their proposed system, the loan departments of banks would remain able to perform both maturity and risk transformation. The principle of fractional-reserve banking would still apply for deposits fulfilling an investment function: "savings or time deposits would, as at

\footnotetext{
${ }^{28}$ As one could have expected, the proposal was understood quite differently by the bankers in general, although several of them endorsed the plan. As Robert Dimand (1993, p. 70) reported: "The banking community remained, however, generally hostile. Such writers as Robinson (1937) and Hackett (1945) viewed deposits from the standpoint of the banks whose liabilities they were, instead of concentrating on which deposits could serve as means of payments. Chequing and savings deposits both enabled fractional-reserve banks to channel savings to borrowers, so Robinson and Hackett saw no case for treating the two types of deposits so differently."

${ }^{29}$ It seems, moreover, that had Fisher considered the variations of $V$ as a leading factor of instability, his proposed solution would still not have been the abolition of banking. Instead, he would have considered a system of taxing the currency, on the stamp scrip model, so as to increase or decrease its velocity of circulation (see Fisher, 1997b [1935], p. 102). When asked if the ' $V$ ' in the equation of exchange had not been neglected in his $100 \%$ plan, Fisher replied: "This is quite true. I, at one time, tried to introduce into the plan a tax method to control the influence of ' $\mathrm{V}$ '. But I left it out as soon as I found that ' $\mathrm{V}$ ' is really nearly constant under conditions which would prevail if the $100 \%$ plan were in operation" (Fisher, letter to Theodore Morgan, 25 September 1945, in Fisher, 1997c, p. 242).
} 
present, normally be covered only fractionally by cash reserves" (Fisher et al., 1939, p. 32) The reserve requirements for those deposits, if any, would be fixed by banking regulation, independently from the proposed monetary reform ${ }^{31}$. Currie and Fisher's aim was not to remove all risk from the activity of banking, but, rather, to shelter the volume of money from this (necessarily risky) activity. Their main point of concern, regarding the loan departments of banks, was thus to make sure that the liabilities they created (i.e. savings deposits) could not be used as means of payment. To this effect, they recommended a legal prohibition of the use of money substitutes in transactions (Currie, 1968b [1934], p. 199; Fisher, 1997b [1935], pp. 23, 165), as well as prudential rules aiming to somewhat limit the liquidity of savings deposits $^{32}$. But the fundamentals of banking would be left largely unchanged. Fisher even affirmed that "[i]f demand deposits were backed 100\%, almost all other legal regulations of banks could be abolished" (1935, p. 171). The typical balance sheet of a bank, under this approach, is shown in Table 2 (see Fisher, 1997b [1935], p. 65; Currie, 2004 [1938], p. 360):

Table 2 Typical bank balance sheet under the Currie-Fisher approach

\begin{tabular}{|l|l|}
\hline \multicolumn{2}{|l|}{$\begin{array}{l}\text { Check department } \\
\text { Deposits in custody }\end{array}$} \\
\hline $\begin{array}{l}\text { 100\% reserves in lawful money } \\
\text { Loan department }\end{array}$ & Transferable ('checking') deposits \\
Assets & Liabilities \\
\hline $\begin{array}{l}\text { (Fractional, or zero) reserves } \\
\text { Loans, investments, etc. }\end{array}$ & $\begin{array}{l}\text { Equity } \\
\text { Non-transferable ('savings') deposits }\end{array}$ \\
\hline
\end{tabular}

The same conditions would apply to the banks' own transactions, as Fisher specified: “The loan department. ... would deposit its own cash in the check department and would transfer it

\footnotetext{
${ }^{30}$ For this reason, it is obviously misleading to refer to the $100 \%$ money concept as 'full-reserve banking'. Fractional-reserve banking, under the Currie-Fisher approach, would still exist; only, there would be full-reserve money, separated from banking.

${ }^{31}$ Fisher would, personally, have these requirements strengthened somewhat (1997b [1935], p. 13), while Currie would have them reduced to zero (Currie, 1968b [1934], p. 199; 2004 [1938], p. 361).

${ }^{32}$ Fisher et al. (1939, p. 32), for example, recommended that savings deposits "should be withdrawable only upon adequate notice". See also Currie (1968b [1934], p. 200) and Fisher (1997b [1935], pp. 1656) for other suggested safeguards.
} 
by check just like any other depositor" (Fisher, 1997b [1935], p. 69) ${ }^{33}$. Very similar 100\% money schemes, insofar as financial intermediation was concerned, would be supported by Richard Lester (1935 p. 37) and George Tolley (1962, p. 304) ${ }^{34}$, and suggested by James Tobin $(1987 \text { b, p. } 3484)^{35}$.

Under this Currie-Fisher approach to the $100 \%$ money reform, the banks would not be the actors most affected. The major change would rather concern the monetary authority, who would be vested, under this plan, with the responsibility of directly providing the economy with all the means of payment needed. This explains why, as Stephen McLane remarked, Fisher focused his attention on this issue:

Throughout his plan, Fisher is more concerned with the central banking structure than with alternatives to commercial banks. Where the Chicago Plan drastically changed private banks ..., Fisher directed his emphasis toward the creation of a new monetary authority, the Currency Commission. . . . Fisher envisioned some nonspecific restriction on the convertibility of time deposits, but saw no need to break up existing financial institutions. (McLane, 1980, p. 89)

\subsection{The Chicago Plan approach: Toward the end of banking}

${ }^{33}$ Of course, those deposits held by the loan department should be included in the money supply calculation, if one defined $M$ as $M o \cup M^{\prime}$. But they would be excluded if, instead, one restricted $M$ to currency in circulation plus checking deposits held by the non-bank public. Such limited definition led Robinson (1937, pp. 442-5) and Watkins (1938, p. 440) to consider that $M$ would still vary endogenously, under a $100 \%$ system, whenever money would be transferred to or from savings accounts.

${ }^{34}$ The old $19^{\text {th }}$ century proposals seem to have followed this approach as well. Carroll, in 1860, had called for $100 \%$ reserves behind demand deposits, "but he would not have interfered with the operation of savings departments" (Mints, 1945, p. 156). Under Walras's plan for a Transfer Bank, too, private banks would still finance loans and investments out of savings deposits: "Discount banks would receive interest-bearing deposits of a fixed term of one month, three months, one year, and have in their portfolios all the securities of the circulating capital; their cash balances as short-term credit entrepreneurs would be kept at the Transfer Bank" ["Les banques d'escompte recevraient des dépôts à intérêt à échéance fixe de un mois, trois mois, un an, et elles auraient en portefeuille tous les titres du capital circulant ; leur encaisse d'entrepreneurs de crédit à courte échéance serait à la Banque de virements."] (Walras, 1898, p. 396, my translation).

${ }^{35}$ However, Tobin's proposals for a 'deposited currency', which he developed in other writings (Tobin, 1985; 1987a), followed more specifically the concept of narrow banking, rather than that of $100 \%$ money. Under his plans, indeed, the liabilities attached to segregated funds, invested in eligible safe assets (other than cash), would still be allowed to circulate as means of payment (Tobin, 1985, p. 27; 1987a, p. 173). The main objective of Tobin's proposals - like those of narrow banking — was to secure the payment system. In contrast, the main objective of the $100 \%$ money proposal was to end the 'perverse elasticity' of the money supply; "safeguarding depositors" was seen by Fisher (1937, p. 296) as a major benefit of the reform, but of "secondary importance". 
The authors of the Chicago Plan, as we have seen, extended their definition of money to liquid assets, and considered the creation of liquidity by banks to be as problematic as their creation of means of payment. They could not, therefore, be satisfied with a simple change of the social convention deciding what was acceptable as a medium of exchange. In their view, the link between banking and velocity (which they related to the supply of 'near monies') also had to be broken. This required a structural change of banking institutions:

More striking is the fact that Currie's narrow definition of money seems to explain his characterizing as ideal . . . a system which would represent only a small first step toward an ideal financial structure. . . To argue that the functions of commercial banks might be assumed without much disturbance by savings banks, amounts almost to recommending drastic changes on the grounds that their intended effects would never be realized. (Simons, 1935, p. 557)

Hence, what the Chicago Plan authors aimed to achieve was "the outright abolition of deposit banking on the fractional-reserve principle" (Simons et al., 1994 [1933], p. 32). Under their plan, banks would be stripped of their lending function, and confined to the administration of checking accounts. Their lending activity would be taken over by other kinds of institutions, which would not be allowed to collect deposits (see Table 3$)^{36}$ :

A second type of institution, substantially in the form of the investment trust, would perform the lending functions of existing banks. Such companies would obtain funds for lending by sale of their own stock; and their ability to make loans would be limited by the amount of funds so obtained. (Simons, 1948 [1934], pp. 64-5)

Table 3 Typical balance sheets of banks and investment trusts under the Chicago Plan

\section{Deposit banks}

Deposits in custody

\begin{tabular}{l|l}
\hline $100 \%$ reserves in lawful money & Transferable ('checking') deposits
\end{tabular}

Investment trusts

Assets Liabilities

Loans, investments, etc. Equity

\footnotetext{
${ }^{36}$ If one followed this approach, then a case could also be made for eliminating all "government facilitation of 'safe asset' creation by the shadow-banking sector", which assets tend to be regarded as "free of credit risk and hence deposit-like", as Adam Levitin (2016, pp. 417-8) recently argued.
} 
Charles Whittlesey (1935, p. 22), Milton Friedman (1992 [1960], p. 70) ${ }^{37}$ and Hyman Minsky (1994, p. 20) $)^{38}$ would advocate essentially similar schemes, in which lending banks were replaced by equity-financed institutions, such as investment trusts or mutual funds. In contrast to savings deposits, which have a finite maturity and a fixed nominal value, shares of equity are neither "matured (demand)" nor "maturing" obligations (in Simons's language, 1936, p. 11), and have "contingent" values, "based upon the market value of a portfolio" (Minsky, 1994, p. 20). They were not viewed, therefore, as liquid 'near monies' created out of maturity and risk transformation. Other authors, globally sharing this approach, would nevertheless maintain the banks in their lending function, provided only that the transformation of maturities be restricted. James Angell, for example, suggested that savings deposits be "converted into negotiable interest-bearing time obligations maturing serially, say not more than 20 per cent within three months nor more than 40 per cent within a year" (Angell, 1935, p. 31). Maurice Allais, for his part, would still allow lending banks to offer savings deposits accounts, but on the condition that maturity transformation be specifically forbidden:

Lending banks would, as today, trade in promises to pay, but-in contrast to the present situation - they would be managed on the principle that all lending for a given term would be financed by borrowing of at least the same term. In other words, whereas banks now borrow short to lend long, they would borrow long to lend short. (Allais, 1987, p. 525, original italics; see also 1975, p. 139; 1989 [1977], p. 202) $)^{39}$

The Chicago Plan economists and the other above-mentioned authors, therefore, despite their differences, all called for drastic reforms of banking practices, so as to prevent risk and/or maturity transformations and their destabilizing effects ${ }^{40}$.

Henry Simons, however, went further, and eventually suggested that restrictions should also be placed on the asset side of financial intermediaries' balance sheets. From 1934, as we saw in section 4.2 , he started to condemn all kind of short-term borrowing as a major source of instability. Therefore, he presented the ideal financial system as the following:

\footnotetext{
${ }^{37}$ The paradoxical fact that Friedman, despite his analytical divergences with Simons, came to support an essentially similar banking scheme, was noted by Phillips (1995, p. 208).

${ }^{38}$ In a later text, however, Minsky (1995, p. 8) would-like Tobin-tend to assimilate the concept of $100 \%$ money with the idea of backing checking deposits with safe assets (that is, narrow banking).

${ }^{39}$ Allais (1987, p. 498), designating by $A^{*}(t, \theta)$ "the total amount at time $t$ of the asset items maturing

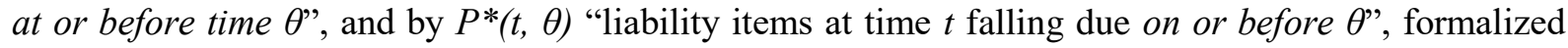
his proposed rule as the following: $P^{*}(t, \theta) \leq A^{*}(t, \theta)$, for any $t$ and $\theta$ (ibid., p. 525).

${ }^{40}$ With the exception, once again, of Friedman (1967, p. 3), who, despite his advocacy of the Chicago Plan reform scheme, seemed to regard this transformation activity favourably.
} 
An approximately ideal condition is fairly obvious - and unattainable. The danger of pervasive, synchronous, cumulative maladjustments would be minimized if there were no fixed money contracts at all -if all property were held in a residual-equity or common-stock form. With such a financial structure, no one would be in a position either to create effective money-substitutes ... or to force enterprises into wholesale efforts at liquidation. (Simons, 1936, pp. 6-7)

Although he recognized that " $[\mathrm{t}] \mathrm{o}$ propose abolition of all borrowing, or even of all borrowing at short term, [was] merely to dream" (ibid., p. 16), he nonetheless called for a "drastic limitation on the formal borrowing-powers of all private corporations" (ibid., p. 30). The abolition of debt contracts became, in his view, a corollary of the $100 \%$ money concept:

In its more important, converse aspect, 100 per cent reserve banking is simply 100 per cent equity financing of all incorporated enterprise. (Simons, 1946, p. 85)

Thus we might arrive at or approach an economy where all private property consisted in pure assets, pure money, and nothing else. This, along with fiscal stabilization of the value of money, is the financial good-society. (ibid., p. 89)

Table 4 shows the balance sheets of financial institutions under Simons's ideal reform plan:

Table 4 Typical balance sheets of deposit banks and investment trusts under Simons's 'financial good society'

\begin{tabular}{|l|l|}
\hline $\begin{array}{l}\text { Deposit banks } \\
\text { Deposits in custody }\end{array}$ & Transferable ('checking') deposits \\
\hline $100 \%$ reserves in lawful money & \\
$\begin{array}{l}\text { Investment trusts } \\
\text { Assets }\end{array}$ & Liabilities \\
\hline $\begin{array}{l}\text { Government consols, corporate } \\
\text { common stock, or real assets }\end{array}$ & Equity \\
\hline
\end{tabular}

\section{The lack of distinction between the two approaches and its consequences}

The divergences between the two approaches to the $100 \%$ money concept presented in this paper, which we referred to as the Currie-Fisher and the Chicago Plan approaches respectively, are fundamental. Their distinction, however, has not been clearly established in the literature. It seems that the very designers of the various plans, themselves, tended to 
underestimate the differences between them. Of those writing in the 1930s, only Simons seemed to be aware of their importance, as revealed his correspondence with Fisher:

In fact, I am more and more convinced of the importance of the point on which we seemed somewhat to disagree. . . Little would be gained by putting demand-deposit banking on a $100 \%$ basis, if that change were accompanied by increasing disposition to hold, and increasing facilities for holding, liquid 'cash' reserves in the form of time-deposits. The fact that such deposits cannot serve as circulating medium is not decisively important; for they are an effective substitute medium for purposes of cash balances. The expansion of [time] deposits ${ }^{41}$, releasing circulating medium from 'hoards', might be just as inflationary as expansion of demand deposits-and their contraction just as deflationary; and the problem of 'runs' would still be with us. (Simons, letter to Fisher, 4 July 1934, in Fisher, 1997c, p. 128)

Fisher, however, did not seem to understand Simons's point. He apparently thought that the latter's concern was only about the risk that savings deposits might be used in transactions:

It seems to me quite preposterous to consider savings deposits as on all fours, or very similar to, deposits subject to check. . . . The statistical fact is that anything held for interest does not circulate as fast as what bears no interest. . . . [W] can iron this out further perhaps but I have not seen anything in any of your statements so far which would seem to me to justify your fears in regard of savings accounts. (Fisher, letter to Simons, 14 December 1934, in Fisher, 1997c, pp. 129-30)

Fisher, as Phillips (1995, p. 92) commented, thus failed to correctly address Simons's concerns. This misunderstanding was all the more unfortunate as, in academic discussions, the fundamental divergence of views between the two groups of authors would be largely ignored, or downplayed. Many commentators seemed to consider that the allowance of fractional-reserve banking, under Currie's and Fisher's 100\% plans, resulted from some kind of 'omission' in their analysis. It was often considered that they had failed either to recognize the monetary nature of savings deposits ${ }^{42}$, or to realize that such deposits, under a $100 \%$ system, could still be exposed to runs and occasion sharp variations in the velocity of money ${ }^{43}$. Some critics even implied that Currie and Fisher were not aware that fractionalreserve banking would still occur under their proposed plans ${ }^{44}$. These opinions could certainly

\footnotetext{
${ }^{41}$ Here, Simons wrote "demand deposits", but this was obviously a typing error.

${ }^{42}$ See Neuman (1937, p. 62), Robinson (1937, p. 42), and Reeve (1943, p. 324).

${ }^{43}$ See Lehmann (1936, p. 44), Neuman (1937, p. 61), Robinson (1937, p. 440), Watkins (1938, p. 442), Brown (1940, p. 312), Thomas (1940, p. 315), and Reeve (1943, p. 324).

${ }^{44}$ See Robinson (1937, p. 442), Brown (1940, p. 312-3), and Higgins (1941, p. 94$)$.
} 
be explained, in part, by the fact that their writings sometimes showed some ambiguity. Fisher, for example, did imply on many occasions that he was condemning the fractionalreserve principle per se (see, for example, Fisher, 1997b [1935], pp. 7-8, 19, 36, 155), while he actually accepted this principle for deposits as long as they could not be used in transactions. At any rate, the preservation of (fractional-reserve) banking under Currie's and Fisher's proposals was, usually, simply viewed as a mistake, rather than being reconciled with their own theories of money. As a result, while the Chicago Plan's proposition to replace lending banks with investment trusts was widely regarded as dangerous ${ }^{45}$, it was nevertheless often viewed as a necessary measure should the plan stand a chance to meet its objective ${ }^{46}$. This may help explain why, as Whalen observed, "the concept of '100 percent' money has often been (sometimes still is) referred to as the "Chicago Plan"' (Whalen, 1994, p. 27).

The idea that the $100 \%$ money proposal necessarily involves replacing the banks by equity-financed institutions would appear again in later debates. Douglas Diamond and Philip Dybvig, for example, when discussing the concept in the 1980s, held the following view:

[The $100 \%$ reserve proposal] specifically restricts banks from entering the transformation business (they cannot hold illiquid assets to transform into liquid assets), and therefore the proposal precludes banks from performing their distinguishing function. (Diamond and Dybvig, 1986, p. 65)

This assimilation of the $100 \%$ money proposal to the kind of reform specifically advocated under the Chicago Plan approach led them to conclude that it was a "dangerous proposition" (ibid., p. 66). A recent study by the International monetary fund, entitled "The Chicago Plan revisited" (Benes and Kumhof, 2012), while advocating the $100 \%$ money reform idea, also regarded it as necessarily implying the end of banking. Its authors, unfortunately, somewhat misrepresented the views of the originators of the proposal. They wrongly affirmed, for example, that Simons and Fisher advocated "more [governmental] control over bank lending", and implied that both of them suggested "eliminating private debt funding (but not equity funding) of banks' residual lending business" (ibid., p. 19). The view that Fisher and the Chicago economists alike would impose $100 \%$ reserves behind all deposits has been recently

\footnotetext{
${ }^{45}$ See Lehmann (1936, p. 43), Neuman (1937, p. 62), Robinson (1937, p. 439), Watkins (1938, p. 445), and Thomas (1940, p. 317).

${ }^{46}$ See Neuman (1937, p. 61), Robinson (1937, p. 440), Thomas (1940, pp. 315, 323), and, more recently, Goodhart and Jensen (2015, p. 23).
} 
carried on by other writers ${ }^{47}$, sometimes relying on this IMF study for their own discussions of the $100 \%$ money idea. This lack of differentiation between the two kinds of plans may have, to some extent, biased the discussions regarding the merits and limits of the proposal ${ }^{48}$.

\section{Conclusion}

The $100 \%$ money proposal would have very different implications for the banking sphere, depending on how money was defined, and how monetary instability was explained. Two broad approaches to the concept may be distinguished along these lines.

Under the Currie-Fisher approach (or 'transaction approach'), the money supply was defined as including virtually all means of payment, and only means of payment. Monetary instability was primarily explained by the variations in the volume of money $(M)$ which, as long as it depended on bank loans, would obey cumulative processes. These authors did recognize that sharp variations in the velocity of money $(V)$ could also occur. But they considered that such variations only played a secondary, aggravating role in economic fluctuations, not a leading one. They argued, moreover, that the changes in $V$ could always be compensated by adequate changes in $M$. For this reason, the reform plans that they proposed only sought to control the volume of money, by changing the social convention deciding what could be used, or not, as a means of payment - only lawful money issued by the state, or bank deposits fully covered in lawful money, could fulfil that role. This fundamentally monetary reform did not imply, for Currie and Fisher, any drastic reform of the proper banking activity. Banks, as financial intermediaries, would remain perfectly free to issue promises to pay beyond their cash reserves, and to create liquidity by performing risk and maturity transformation - as long as those same promises were not allowed to circulate as means of payment. Under the Currie-Fisher approach, 100\% money would spell the end of fractionalreserve money, but not of fractional-reserve banking.

Under the Chicago Plan approach (or 'liquidity approach'), the money supply was defined as including not only means of payment, but also liquid assets, such as savings deposits. The

\footnotetext{
${ }^{47}$ See, for example, Wolf (2014, p. 210), Turner (2016, p. 10), King (2016, p. 262), or Glasner (2017, p. 32). An opposite confusion - that the Chicago Plan would, like Fisher's Plan, still allow banks to lend from savings deposits — can be found in Allais (1987, pp. 523-4) and Levitin (2016, p. 419).

${ }^{48}$ The $100 \%$ money idea has been criticized, for example, by Adair Turner (2016, pp. 188-90) mainly on the ground that it would prevent the banks from performing maturity transformation, and by Mervyn King (2016, pp. 262-4) mainly on the ground that it would prevent them from performing risk transformation.
} 
variations in the volume of means of payment $(M)$ were not regarded as the sole primary cause of monetary instability. Sharp variations in their velocity of circulation $(V)$, induced in particular by variations in the quantity of 'near monies' (liquid assets), were attributed a leading role too, capable in itself to generate cumulative processes. The activity of banking, therefore, was viewed as inherently dangerous for the whole economy, not only because the banks' promises to pay could be used in transactions, but also because banks created liquidity when performing risk and maturity transformation. For this reason, in addition to changing the monetary social convention, the Chicago Plan would abolish banks as lending institutions working with savings deposits, and replace them with investment trusts working with equity shares. Under the Chicago Plan approach, $100 \%$ money would not only spell the end of fractional-reserve money, but also the end of banking - and, potentially, the end of all kinds of debt contracts, if one followed Simons's reasoning to its logical conclusion.

Table 5 Summary of the divergences between the Currie-Fisher and the Chicago Plan approaches to the $100 \%$ money proposal ${ }^{49}$

\begin{tabular}{|l|l|l|}
\cline { 2 - 3 } \multicolumn{1}{c|}{} & $\begin{array}{l}\text { Currie-Fisher (or } \\
\text { 'transaction') approach }\end{array}$ & $\begin{array}{l}\text { Chicago Plan (or } \\
\text { 'liquidity') approach }\end{array}$ \\
\hline Definition of money & Means of payment & $\begin{array}{l}\text { Means of payment } \\
+ \text { liquid assets }\end{array}$ \\
\hline $\begin{array}{l}\text { Leading factors of } \\
\text { instability }\end{array}$ & Instability of $M$ & $\begin{array}{l}\text { Instability of } M \\
+ \text { instability of } V\end{array}$ \\
\hline Reform proposals & Monetary reform & $\begin{array}{l}\text { Monetary reform } \\
+ \text { banking reform }\end{array}$ \\
\hline
\end{tabular}

Although the divergences between these two approaches (summarized in Table 5) are fundamental, they have not been clearly identified and discussed in the literature. This lack of differentiation might help explain why, in many instances, the $100 \%$ money proposal has been assimilated to the specific Chicago Plan for banking reform, and considered as necessarily involving the 'end of banking'. One may wonder if such confusion has not, to some extent, biased the discussions regarding the merits and limits of the proposal.

${ }^{49}$ Of course, this distinction should not be interpreted too rigorously, and any classification of $100 \%$ money proponents according to the two approaches should be made carefully. Indeed, some authors, while following one or the other approach about banking reform, would at the same time rather follow the opposite approach when it comes to defining money or explaining monetary instability.

${ }^{50}$ With $M$ representing here the volume of the means of payment, and $V$ their velocity of circulation. 


\section{Acknowledgements}

I would like to thank Juan Carlos Acosta, Robert W. Dimand, Rebeca Gomez Betancourt, Laurent Le Maux, Ronnie J. Phillips, Roger Sandilands and Adrien Vila for helpful comments or discussions in relation with this paper. I am also grateful to two anonymous referees for their valuable remarks and recommendations.

\section{References}

Allais, M. 1947. Économie et intérêt : présentation nouvelle des problèmes fondamentaux relatifs au rôle économique du taux de l'intérêt et de leurs solutions. Paris, France: Librairie des publications officielles.

Allais, M. 1975. Le Concept de monnaie, la création de monnaie et de pouvoir d'achat par le mécanisme du crédit et ses implications. In: Coulbois, P., ed. Essais en l'honneur de Jean Marchal. 2, La monnaie, 106-45. Paris : Cujas.

Allais, M. 1987. The credit mechanism and its implications. In: Feiwel, G., ed. Arrow and the foundations of the theory of economic policy. New York, NY: New York University Press.

Allais, M. 1989 [1977]. L'Impôt sur le capital et la réforme monétaire. Nouvelle édition, précédée d'un auto-portrait scientifique. Paris: Hermann.

Allen, W.R. 1993. Irving Fisher and the 100 percent reserve proposal. Journal of law and economics, $36(2), 703-17$.

Angell, J.W. 1935. The 100 per cent reserve plan. The quarterly journal of economics, 50 (1), 1-35.

Barber, G.R. 1973. The one hundred percent reserve system. The American Economist, 17 (1), 115-27.

Benes, J. and Kumhof, M. 2012. The Chicago Plan revisited. IMF Working Paper WP/12/202, International monetary fund.

Brown, H.G. 1936. Objections to the 100 percent plan. The American economic review, XXVI (3), 309-14.

Currie, L. 1968a [1934]. The supply and control of money in the United States. Reprinted with an additional report by L. Currie, and a prefatory paper by K. Brunner. New York, NY: Russell \& Russell, and Cambridge, MA: Harvard University Press.

Currie, L. 1968b [1934]. A proposed revision of the monetary system of the United States, submitted to Secretary of the Treasury Henry Morgenthau, September 1934. In: Currie, L. The supply and control of money in the United States. New York, NY: Russell \& Russell, and Cambridge, MA: Harvard University Press, 1968, 195-226.

Currie, L. 2004 [1938]. The 100 percent reserve plan, August 12, 1938. Journal of economic studies, $31(3 / 4), 355-65$. 
Diamond, D. and Dybvig, P. 1986. Banking theory, deposit insurance, and bank regulation. The journal of business, 59 (1), 55-68.

Dimand, R.W. 1993. 100 percent money-Irving Fisher and banking reform in the 1930s'. History of economic ideas, 1 (2), 59-76.

Fisher, I. 1934. Monetary cure for depression. Address to the Controllers Institute of America, September 18, 1934. The Controller, Oct. 1934, 155-68.

Fisher, I. 1937. Note suggested by review of '100 per cent money'. Journal of the Royal Statistical Society, 100 (2), 296-98.

Fisher, I. 1947. Our inflation and deflation, How come? How conquered? Dated 26 February 1947, revised 26 March 1947. Unpublished. Fisher Papers, Yale University.

Fisher, I. 1997a [1911]. The purchasing power of money. Reprint, with new editorial content, of the 2nd ed., revised, 1913. The works of Irving Fisher. Vol. 4. Ed. W.J. Barber, assisted by R.W. Dimand and K. Foster, consulting ed. J. Tobin. London: Pickering \& Chatto.

Fisher, I. 1997b [1935]. $100 \%$ money. Reprint, with new editorial content, of the 3rd ed., 1945, itself a reprint, with new preface and addendum, of the 2nd ed., revised, 1936. The works of Irving Fisher. Vol. 11. Ed. W.J. Barber, assisted by R.W. Dimand and K. Foster, consulting ed. J. Tobin. London: Pickering \& Chatto.

Fisher, I. 1997c. Correspondence and other commentary on economic policy 1930-1947. The works of Irving Fisher. Vol. 14. Ed. W.J. Barber, assisted by R.W. Dimand and K. Foster, consulting ed. J. Tobin. London: Pickering \& Chatto.

Fisher, I. et al. 1939. A program for monetary reform. Co-signed by Paul Douglas, Irving Fisher, Frank D. Graham, Willford King, Earl Hamilton and Charles Whittlesey, dated July 1939, unpublished.

Friedman, M. 1948. A monetary and fiscal framework for economic stability. The American economic review, 38 (3), 245-64.

Friedman, M. 1967. The monetary theory and policy of Henry Simons. The journal of law \& economics, 10, 1-13.

Friedman, M. 1992 [1960]. A program for monetary stability. 10th printing, with new preface. New York: Fordham University Press.

Friedman, M. and Schwartz, A.J. 1963. A monetary history of the U.S. - 1867-1960, Princeton University Press.

Glasner, D. 2017. Rules versus discretion in monetary policy historically contemplated. Journal of macroeconomics, 54, 24-41.

Goodhart, C.A.E. and Jensen, M.A. 2015. A commentary on Patrizio Lainà's 'Proposals for full- 
reserve banking: a historical survey from David Ricardo to Martin Wolf'. Currency School versus Banking School: an ongoing confrontation. Economic thought, 4 (2), 20-31.

Hart, A.G. 1935. The "Chicago Plan" of banking reform, a proposal for making monetary management effective in the United States. Review of economic studies, 2 (2), 104-16.

Higgins, B. 1941. Comments on 100 percent money. The American economic review, XXXI (1), 91-6.

Huber, J. 2017. Sovereign money - beyond reserve banking. London: Palgrave Macmillan.

Huber, J. and Robertson, J. 2000. Creating new money. A monetary reform for the information age. New Economics Foundation.

Huerta de Soto, J. 2012 [1998]. Money, bank credit, and economic cycles, 3rd English edition, Auburn: Ludwig von Mises Institute. First Spanish edition: Dinero, crédito bancario y ciclos económicos, 1998, Madrid: Unión Editorial.

Jackson, A. and Dyson, B. 2013. Modernising money. Why our monetary system is broken and how it can be fixed. London: Positive Money.

King, M. 2016. The end of alchemy - Money, banking, and the future of the global economy. New York: W. W. Norton \& Company.

Knight, F.H. et al. 1995 [1933]. Memorandum on banking reform. Dated March 1933, first published as an appendix in Phillips, R.J. The Chicago Plan and New Deal banking reform, Armonk, N.Y: Routledge, 1995, 191-9.

Kotlikoff, L.J. 2010. Jimmy Stewart is dead - Ending the world's ongoing financial plague with limited purpose banking. Hoboken, NJ: John Wiley \& Sons.

Laidler, D. 1999. Fabricating the Keynesian revolution. Cambridge, UK: Cambridge University Press.

Lainà, P. 2015. Proposals for full-reserve banking: a historical survey from David Ricardo to Martin Wolf. Economic Thought, 4 (2), 1-19.

Lehmann, F. 1936. 100\% money. Social research, 3 (1), 37-56.

Lester, R.A. 1935. Check-book inflation. The American scholar, 4 (1), 30-40.

Levitin, A.J. 2016. Safe banking: finance and democracy. The University of Chicago Law Review, 83 (1), 357-455

Litan, R.E. 1987. What should banks do? Washington, D.C.: The Brookings Institution

McLane, S.E. 1980. Improving monetary control: the abolition of fractional reserves, New Brunswick, N.J.: The Stonier Graduate School of Banking.

Minsky, H.P. 1994. Financial instability and the decline (?) of banking: future policy implications. Working paper No. 127, October 1994. The Jerome Levy Research Institute of Bard College.

Minsky, H.P. 1995. Would universal banking benefit the U.S. economy? Hyman P. Minsky Archive, Paper 51, reworked version dated 5 April 1995. 
Mints, L.W. 1945. A history of banking theory in Great Britain and the United States. Chicago: University of Chicago Press.

Mises, L. (von). 1953 [1912]. The theory of money and credit. 2nd ed. English translation by H.E. Batson. New Haven: Yale University Press. First German edition: Theorie des Geldes und der Umlaufsmittel, 1912, Munchen und Leipzig: Ferlag von Duncker \& Humblot.

Neuman, A. M. 1937. 100 per cent. money. The Manchester school, 8 (1), 56-62.

Phillips, R.J. 1988. Veblen and Simons on credit and monetary reform. Southern economic journal, 55 (1), 171-81.

Phillips, R.J. 1995. The Chicago Plan and New Deal banking reform. With a foreword by Hyman Minsky. Armonk, N.Y: Routledge.

Reeve, J.E. 1943. Monetary reform movements. Washington: American Council on Public Affairs.

Robinson, G.B. 1937. 100\% bank reserves. Harvard business review (Summer), 438-47.

Rothbard, M.N. 1962. The case for a 100-percent gold dollar. In: Yeager (ed.), In search of a monetary constitution. Cambridge, Massachusetts: Harvard University Press, 1962, 94-136.

Sandilands, R. 2004. New light on Lauchlin Currie's monetary economics in the New Deal and beyond. Journal of economic studies, 31 (3/4), 170-97.

Schiming, R.C. 1996. Reviewed work: the Chicago Plan \& New Deal banking reform, by Ronnie J. Phillips. The journal of economic history, 56 (1), 264-5.

Sigurjónsson, F. 2015. Monetary reform - A better monetary system for Iceland. A report by Frosti Sigurjónsson, Commissioned by the Prime minister of Iceland.

Simons, H.C. 1935. Reviewed work: The supply and control of money in the United States, by Lauchlin Currie. Journal of political economy, 43 (4), 555-8.

Simons, H.C. 1936. Rule versus authorities in monetary policy. Journal of political economy, 44 (1), $1-30$.

Simons, H.C. 1946. Debt policy and banking policy. The review of economics and statistics, 28 (2), 85-9.

Simons, H.C. 1948 [1934]. A positive program for laissez-faire. In: Simons, H. C., Economic policy for a free society, Chicago: University of Chicago Press, 1948, 40-77. Originally published in Simons, H.C., A positive program for laissez-faire. Public policy pamphlet No 15, Chicago: University of Chicago Press, 1934.

Simons, H.C. et al. 1994 [1933]. Banking and currency reform. Memorandum dated November 1933, first published in Warren Samuels (ed.), Research in the history of economic thought and methodology, archival supplement 4, JAI Press Inc., 31-40. 
Soddy, F. 1933 [1926]. Wealth, virtual wealth and debt, 2nd ed. London: Britons Publishing Company.

Thomas R.G. 1940. 100 per cent money: the present status of the 100 per cent plan. The American economic review, 30 (2), Part 1, 315-23.

Tobin, J. 1985. Financial innovation and deregulation in perspective. Bank of Japan Monetary and economic studies, III, 19-29.

Tobin, J. 1987a. The case for preserving regulatory distinctions. In: Restructuring the financial system, Kansas City: Federal Reserve Bank of Kansas City, 167-83.

Tobin, J. 1987b. Financial intermediaries. In: Eatwell, J., Milgate, M. and Newman, P., eds. The New Palgrave: a dictionary of economics. London: Palgrave Macmillan, 3470-87.

Tolley, G.S. 1962. 100 per cent reserve banking. In: Yeager, ed. In search of a monetary constitution. Cambridge, Massachusetts: Harvard University Press, 275-304.

Turner, A. 2016. Between debt and the devil. Princeton, NJ: Princeton University Press.

Walras, L. 1898. La caisse d'épargne postale de Vienne et le comptabilisme social. In: Walras, L. Études d'économie politique appliquée : théorie de la production de la richesse sociale, Lausanne: F. Rouge; Paris: F. Pichon, 376-98. Originally published in Revue d'économie politique, 12 (3), March 1898, 202-20.

Warburton, C. 1949. The secular trend in monetary velocity. The quarterly journal of economics, 63 (1), 68-91.

Watkins L.L. 1938. Commercial banking reform in the United States: with especial reference to the 100 per cent plan and the regulation of interest rates on bank deposit. Michigan business studies VIII (5), Ann Harbor: University of Michigan.

Whalen, C.J. 1988. The Minsky-Simons connection: a neglected thread in the history of economic thought. Journal of economic issues, 22 (2), 533-44.

Whalen, C.J. 1994. Henry Simons on banking and currency reform: an introduction. In: Warren Samuels, ed. Research in the history of economic thought and methodology, archival supplement 4, JAI Press Inc., 23-9.

Whittlesey, C. 1935. Banking and the New Deal. Public policy pamphlet No. 16. Chicago: University of Chicago Press.

Wolf, M. 2014. The shifts and the shocks: what we've learned - and have still to learn - from the financial crisis. London: Penguin Books.

Wray, L.R. 2015 (2012). Modern money theory: A primer on macroeconomics for sovereign monetary systems. Second edition, New York: Palgrave Macmillan. 